\title{
Laudatio for Professor Peter Kroll
}

Peter Kroll was born in Bratislava in the Slovak Republic on 16 May 1943. He graduated from medical school in 1971 and wrote his postgraduation thesis in 1973 at the University of Bonn. Peter Kroll also completed a residency in Ophthalmology in 1978 at the University Eye Hospital in Bonn. Dr. Kroll joined the University Eye Clinic in Münster in 1978 as faculty ophthalmologist, where he obtained his professorship in 1983. In 1989 Professor Peter Kroll was elected chairman and head Professor in the Ophthalmology Department of the Philipps-Universität Marburg.

Professor Kroll made the Department of Ophthalmology in small historic Marburg achieve international recognition as a major center in vitreoretinal diseases and surgery. With his great friend and fellow Dr. Jörg Schmidt, Professor Kroll developed one of the most outstanding and highest-quality vitreoretinal surgeries in the world. Throughout the years the reference eye clinic in Marburg has attracted patients and professional visitors from all over the world including Mexico, Russia, USA, France, Spain, Brazil and China. Professor Kroll's personal goal has been to train a few fellows very well and enable them to perform high-standard vitrectomy to

Dr. Eduardo Büchele Rodrigues studied and learned vitreoretinal diseases/surgery under Professor Peter Kroll's guidance as a German Academic Exchange Service (DAAD) scholar fellow during the years 2001-2004.

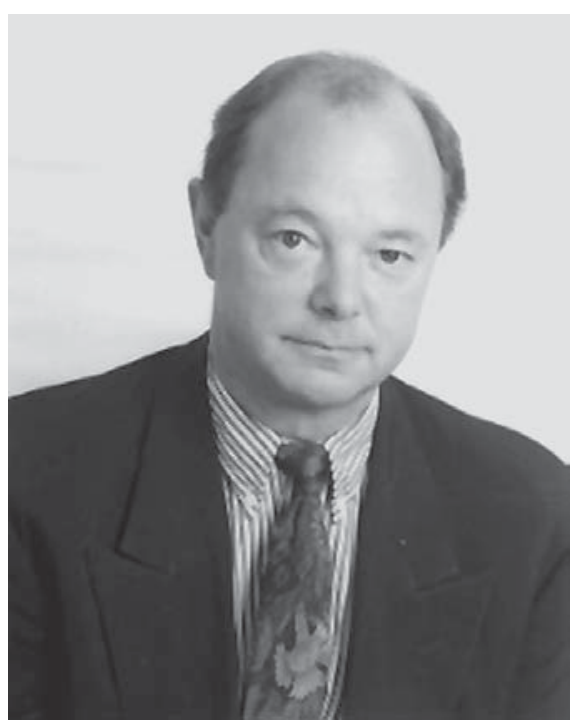

work in the interest of their patients. Professor Kroll's productive career comprises over 250 publications in internationally recognized scientific journals and 1 book of ophthalmology. Through his career he has been recognized as a permanent member of several important retina societies including the Club Jules Gonin and the former Vitreous Society.

Professor Kroll has made remarkable contributions to the understanding and treatment of diabetic retinopathy and implemented substantial innovations. Major achieve-

\section{KARGER}

Fax +41613061234

E-Mail karger@karger.ch

www.karger.com
(C) 2007 S. Karger AG, Basel

0030-3755/07/2212-0075\$23.50/0

Accessible online at:

www.karger.com/oph 
ments in his lifelong engagement in treating diabetic eye disease include the foundation and presidency of the IFdA, German abbreviation for 'Initiativgruppe Früherkennung diabetischer Augenerkrankungen', and the introduction of a classification of proliferative diabetic vitreoretinopathy [1]. Kroll's classification strengthens the role of the vitreous in the pathogenesis of diabetic vitreoretinopathy, as he has been the world's pioneer in determining the vitreoretinal interface key for proliferative diabetic vitreoretinopathy disease progression [2]. Consequently, early vitrectomy may provide better outcomes in rapidly progressing diabetic vitreoretinopathy patients $[3,4]$. His struggle in this field as head of the IFdA association promoted significant reduction in blindness due to diabetic retinopathy in Europe. Further remarkable scientific contributions by Professor Kroll and his assistants in Marburg include the enzymatic removal of the posterior vitreous cortex, therapy of proliferative vitreoretinopathy secondary to rhegmatogenous retinal detachment and advances in chromovitrectomy [5-7].
As a chairman and leader Professor Kroll possesses remarkable emotional intelligence to select assistants with integrity as the main criterion. He enjoys having young German and foreign fellows around and taking care of them. To his fellows and colleagues, he has been a leader and motivator of original and innovative thinking. Besides being a great surgeon, teacher and researcher, he is an extraordinary human being with an incredible appetite for the world and all of its beauty. His tremendous dignity, simplicity with elegance and pleasant humor are remembered by all those who spend time with him. Professor Kroll has maintained a close and strong friendship with Professor C. Ohrloff, Professor H. Kaufmann and Professor $\mathrm{H}$. Busse for many decades.

It is with great pleasure that the journal Ophthalmologica and his retina colleagues acknowledge Professor Peter Kroll, one of the most impressive leaders in diabetic retinopathy and vitreoretinal surgery, for his multitude of contributions.

Eduardo Büchele Rodrigues

Institute of Vision, Federal University of São Paulo (Brazil)

\section{References}

1 Hesse L, Heller G, Kraushaar N, Wesp A, Schroeder B, Kroll P: The predictive value of a classification for proliferative diabetic vitreoretinopathy. Klin Monatsbl Augenheilkd 2002;219:46-49.

2 Kroll P, Meyer-Rusenberg HW, Berg P: Does vitrectomy in proliferative diabetic retinopathy effect an improvement in intraocular metabolic status? Fortschr Ophthalmol 1986;83:471-473.
3 Bodanowitz S, Hesse L, Weinand F, Kroll P: Vitrectomy in diabetic patients with a blind fellow eye. Acta Ophthalmol Scand 1996;74: 84-88.

4 Hoerle S, Poestgens H, Schmidt J, Kroll P: Effect of pars plana vitrectomy for proliferative diabetic vitreoretinopathy on preexisting diabetic maculopathy. Graefes Arch Clin Exp Ophthalmol 2002;240:197-201.

5 Hesse L, Kroll P: Enzymatically induced posterior vitreous detachment in proliferative diabetic vitreoretinopathy. Klin Monatsbl Augenheilkd 1999;214:84-89.
6 Schmidt JC, Rodrigues EB, Hoerle S, Meyer $\mathrm{CH}$, Kroll P: Primary vitrectomy in complicated rhegmatogenous retinal detachment a survey of 205 eyes. Ophthalmologica 2003; 217:387-392.

7 Rodrigues EB, Meyer CH, Kroll P: Chromovitrectomy: a new field in vitreoretinal surgery. Graefes Arch Clin Exp Ophthalmol 2005;243:291-293. 